\title{
Nematodes from galls on Myrtaceae. I. Fergusobia/Fergusonina galls on Corymbia spp., with re-description of $F$. magna and notes on its phylogenetic relationships
}

\author{
KERRIE A. DAVIES ${ }^{1,6}$, ROBIN M. GIBLIN-DAVIS ${ }^{2}$, WEIMIN YE ${ }^{2,3}$, \\ GARY S. TAYLOR ${ }^{4} \&$ W. KELLEY THOMAS ${ }^{5}$ \\ ${ }^{1}$ Australian Centre for Evolutionary Biology and Biodiversity, and School of Agriculture, Food and Wine, The University of Adelaide, \\ Waite Campus, PMB 1, Glen Osmond, South Australia 5064, Australia \\ ${ }^{2}$ Fort Lauderdale Research and Education Center, University of Florida, 3205 College Ave, Davie, Florida 33314-7799, USA. \\ E-mail: giblin@ufl.edu \\ ${ }^{3}$ Present address: Nematode Assay Section, Agronomic Division, North Carolina Department of Agriculture \& Consumer Services, \\ 4300 Reedy Creek Road, Raleigh, NC 27607, USA. E-mail: weimin.ye@ncmail.net \\ ${ }^{4}$ Australian Centre for Evolutionary Biology and Biodiversity, and School of Earth and Environmental Sciences, The University of \\ Adelaide, North Terrace, Adelaide, South Australia 5005, Australia.E-mail: gary.taylor@adelaide.edu.au \\ ${ }^{5}$ Hubbard Center for Genome Studies, University of New Hampshire, 35 Colovos Rd., Durham, NH, 03824, USA. \\ E-mail: kelley.thomas@unh.edu \\ ${ }^{6}$ Corresponding author. E-mail: kerrie.davies@adelaide.edu.au
}

\begin{abstract}
Fergusobia magna (Neotylenchidae: Fergusobiinae), collected from axial bud ('stem') galls on Corymbia tessellaris growing in coastal regions of Queensland, Australia, is re-described. It is characterised by having a combination of a relatively large, variably shaped parthenogenetic female with a slender conoid tail; a relatively large arcuate infective female with a long slender tail with a pointed tip and a relatively anterior vulva; and relatively large, arcuate, open C or Jshaped males with angular spicules having manubrium and shaft forming $66 \%$ of their length, slender tail and peloderan bursa arising at 30-50\% body length. Other known forms of Fergusobia/Fergusonina galls from Corymbia are outlined, and the morphology of nematodes from them and the shield morphology of their associated mutualistic fly species from Corymbia spp. are described where known. The possible phylogenetic relationships of these associations from Corymbia are discussed.
\end{abstract}

Key words: 18S rDNA, 28S rDNA D2/D3, COI, DNA sequencing, Australia, Nematoda, Neotylenchidae, galls, Myrtaceae, Fergusoninidae, flies, molecular phylogeny, morphology, taxonomy, coevolution, cospeciation

\section{Introduction}

In a mutualistic association, nematodes of the genus Fergusobia Currie 1937 (Christie 1941) (Tylenchida: Neotylenchidae) and flies of the genus Fergusonina Malloch 1924 (Diptera: Fergusoninidae) are known to form galls on some Myrtaceae (Currie 1937; Giblin-Davis et al. 2004b; Taylor et al. 2005). Evidence from molecular sequencing of flies and nematodes suggests that each species of Fergusonina is associated with a particular species of Fergusobia, and that almost all mutualisms are plant host species specific (Goolsby et al. 2000; Giblin-Davis et al. 2001; Taylor 2004; Ye et al. 2007; Scheffer unpub. data). Genera known to be hosts for this association include Eucalyptus L'Héritier 1788, Syzygium R. Brown ex Gaertner 1788, Melaleuca Linnaeus 1767, nom. cons., Angophora Cav. 1797, Metrosideros Banks ex Gaertner 1788, Corymbia Hill \& Johnson 1995 (Tonnoir 1937; Harris 1982; Taylor 2004; Davies \& Giblin-Davis 2004; Colbran 1964; Taylor et al. 2005; Taylor et al. 2007) and Leptospermum Forster \& Forster 1776 (Robin Adair, unpub. data). Fergusobia is a speciose genus (Davies et al. 2010). The Waite Insect and Nematode Collection (WINC) at the University of Adelaide contains about 250 collections of Fergusonina flies and about 200 collections of 